\title{
Electrocardiogram Test
}

National Cancer Institute

\section{Source}

National Cancer Institute. Electrocardiogram Test. NCI Thesaurus. Code C83146.

A character or string that represents the full name of the ECG assessment. 